\title{
INVESTIGATING INDOOR AIR QUALITY AND THERMAL COMFORT USING DIFFERENT VENTILATION SYSTEMS UNDER IRAQI CLIMATE
}

\author{
${ }^{1}$ Ala'a Abbas Mahdi \\ alaa.mahdi1959@gmail.com \\ ${ }^{2}$ Sara Mohammed Abbas \\ alifahem1988@gmail.com \\ ${ }^{1,2}$ University of Babylon, College of Engineering / Mechanical Engineering Department.
}

\section{ABSTRACT}

Computational Fluid Dynamics (CFD) of indoor environment as well as quality considerations are important element in the study of energy consumption, thermal comfort and indoor air quality in buildings. This paper investigate a comparison work between impinging jet, displacement, and mixing ventilation systems for an isothermal and nonisothermal ventilated room for Indoor Air Quality (IAQ) and thermal human comfort under Iraqi climate. For IJV system, draught discomfort is the issue of most concern since it supplies cooled air directly to the occupied zone. This study investigated a number of factors influencing draught discomfort and temperature stratification in an office environment. The considered factors, supply airflow rate and supply air temperature. RNG K- $\varepsilon$ turbulence model was used with the turbulent flow. The second aspect included numerical analyses by adopting ANSYS FLUENT15 code to generate simulation models. A square shaped air supply device was used with [0.1 times room height $(\mathrm{h})]$ outlet terminal height from the foot level end. The IJV system proved more efficient than displacement and mixing ventilation systems. The Air Distribution Performance Index (ADPI) obtained for an isothermal and non-isothermal ventilated room adopting IJV system gave best values $(0.80,0.83)$ respectively compared with the other two ventilation systems.

KEYWORD: Impinging jet ventilation, mixing ventilation, displacement ventilation, comparison study, CFD, Indoor air quality, Numerical model, turbulence model.

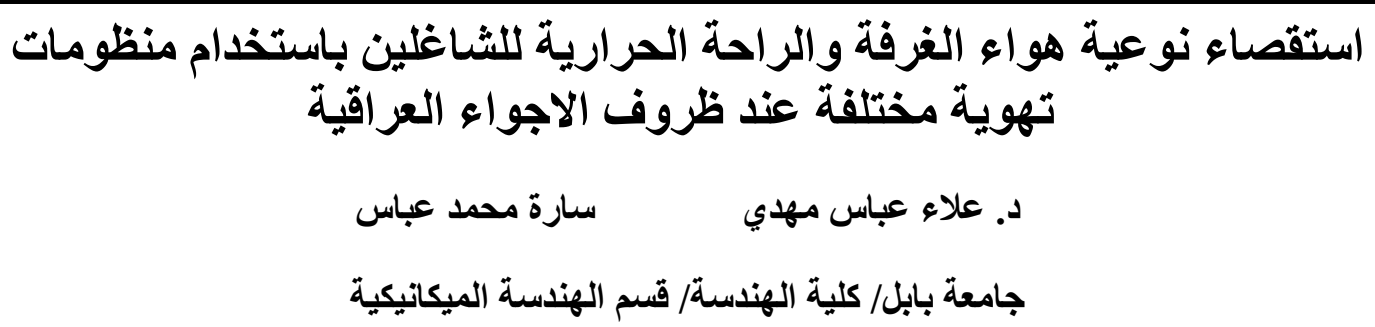

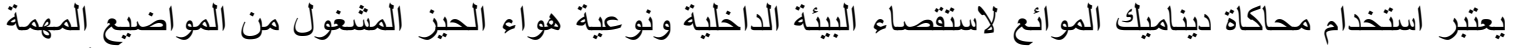

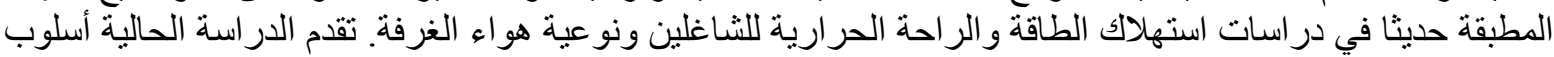

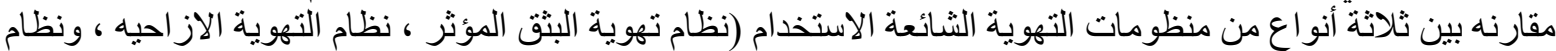

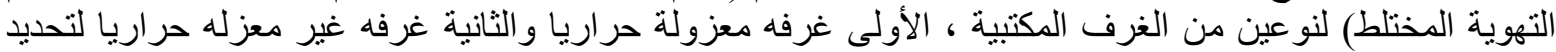

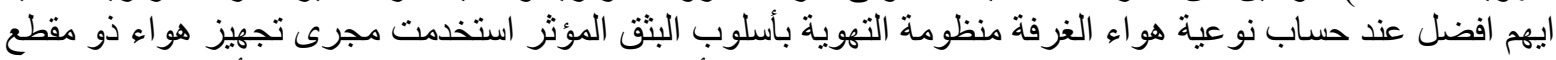

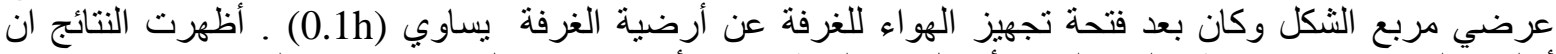

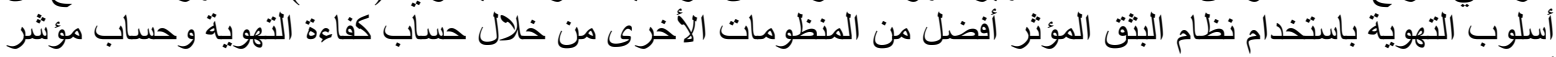




\section{Nomenclature}

\begin{tabular}{|c|c|c|}
\hline Symbols & Description & Unit \\
\hline $\mathrm{A}_{\mathrm{f}}$ & Surface area for floor & $\mathrm{m}^{2}$ \\
\hline $\mathrm{A}_{\mathrm{s}}$ & Face area for diffuser & \\
\hline $\mathrm{C}_{\mathrm{p}}$ & Specific heat of the air at constant pressure. & $\mathrm{kJ} / \mathrm{kg} \cdot \mathrm{K}$ \\
\hline $\mathrm{dx} d \mathrm{dz}$ & Control volume & $\mathrm{m}$ \\
\hline $\mathrm{E}_{\mathrm{ij}}$ & The mean rate of deformation tenser & \\
\hline $\mathrm{g}$ & Gravitational acceleration & $\mathrm{m} / \mathrm{s}^{2}$ \\
\hline $\mathrm{k}_{\mathrm{i}, \mathrm{j}, \mathrm{k}}$ & Turbulent kinetic energy at cell $(\mathrm{i}, \mathrm{j}, \mathrm{k})$ & $\mathrm{m}^{2} / \mathrm{s}^{2}$ \\
\hline $\mathrm{P}$ & Pressure & $\mathrm{N} / \mathrm{m}^{2}$ \\
\hline $\mathrm{P}_{\mathrm{z}}$ & zone population & person \\
\hline $\mathrm{QDV}_{\mathrm{DV}}$ & Air required to satisfy the sensible cooling load in a DV system & $1 / \mathrm{s}$ \\
\hline $\mathrm{q}_{1}$ & Cooling load for the overhead lighting & $\mathrm{W}$ \\
\hline $\mathrm{q}_{\mathrm{oe}}$ & Cooling load for occupants, desk lamps and equipment. & $\mathrm{W}$ \\
\hline $\mathrm{Q}_{\mathrm{oz}}$ & Fresh air flow rate & $1 / \mathrm{s}$ \\
\hline $\mathrm{R}_{\mathrm{A}}$ & Outdoor air flow rate required per unit area & $1 / \mathrm{s}$ \\
\hline $\mathrm{R}_{\mathrm{p}}$ & Outdoor air flow rate required per person & $1 / \mathrm{s}$ \\
\hline $\mathrm{S}$ & Source term for the rate of thermal energy production & $\mathrm{J} / \mathrm{kg}$ \\
\hline $\mathrm{T}_{\mathrm{av}}$ & average room temperature & ${ }^{\circ} \mathrm{C}$ \\
\hline $\mathrm{T}_{\mathrm{i}, \mathrm{j}, \mathrm{k}}$ & Temperature at cell $(\mathrm{i}, \mathrm{j}, \mathrm{k})$ & ${ }^{\circ} \mathrm{C}$ \\
\hline$\Delta \mathrm{T}_{\mathrm{hf}}$ & Temperature difference from head to foot level. & ${ }^{\circ} \mathrm{C}$ \\
\hline $\mathrm{T}_{\mathrm{sp}}$ & Setup (design) temperature. & ${ }^{\circ} \mathrm{C}$ \\
\hline $\mathrm{U}_{\mathrm{s}}$ & Supply air velocity & $\mathrm{m} / \mathrm{s}$ \\
\hline $\mathrm{U}_{\mathrm{x}}$ & Local air velocity & $\mathrm{m} / \mathrm{s}$ \\
\hline
\end{tabular}

Abbreviations

\begin{tabular}{|l|l|}
\hline ASHRAE & American Society for Heating Refrigeration and Air Conditioning Engineer \\
\hline ACH & Air Change per Hour \\
\hline CFD & Computational Fluid Dynamics \\
\hline IAQ & Indoor Air Quality \\
\hline RNG & Re-Normalization Group \\
\hline IJV & Impinging Jet Ventilation \\
\hline MV & Mixing Ventilation \\
\hline DV & Displacement Ventilation \\
\hline
\end{tabular}

\section{Sub-Scripts}

\begin{tabular}{|l|l|l|l|}
\hline av. & Average & sp & Setup \\
\cline { 1 - 2 } f & Floor & t & total \\
\cline { 1 - 2 } l & Room height & \multicolumn{2}{|c}{} \\
\cline { 1 - 2 } & Overhead light & \multicolumn{2}{|c}{} \\
\cline { 1 - 2 } & &
\end{tabular}

\section{Greek letters}

\begin{tabular}{|l|l|l|}
\hline$\rho$ & Air density & $\mathrm{kg} / \mathrm{m}^{3}$ \\
\hline $\mathcal{E}$ & Turbulent energy dissipation rate. & \\
\hline$\sigma$ & Prandtl or Schmidt number & \\
\hline$\omega$ & Specific dissipation rate & $1 / \mathrm{s}$ \\
\hline$\Gamma$ & Diffusion coefficient (diffusivity) & $\mathrm{m}^{2} / \mathrm{s}$ \\
\hline
\end{tabular}




\section{INTRODUCTION}

The target of mixing ventilation applications is to diffuse the supply air into the space so that the thermal conditions and eventual contaminant concentrations are uniform either in the entire space or in a specific zone of the space.

Displacement Ventilation system can be defined as room ventilation created by room air displacement, through delivering air at low level and velocity in a space at a low air temperature to be suitable for large spaces, such as concert halls and workshops. Simply, it defined as any airflow pattern where "old" air displaced by "new" air, Hakon [2010].

Impinging Jet Ventilation (IJV) systems is developed with the aim of combining both mixing and displacement ventilation system, and therefore be able to avoid their disadvantages and seize their advantages. In terms of flexibility, high momentum ventilation systems are better that buoyancy based ventilation systems.

A new method of air distribution, is based on Impinging Jet Ventilation (IJV). This method based on the principle of supplying a jet of air with high momentum downwards onto the floor. As the jet impinges onto the floor it spreads over a large area causing the jet momentum to recede but still has a sufficient force to reach long distances, .Karimipanah \& Awbi [2001].

The supply device of IJV is located at certain distance above the floor. This system combines some characteristics of mixing and displacement ventilation. The most relevant are:

- It supplies air at higher momentum than displacement ventilation systems, and lower momentum than mixing ventilation systems in some cases.

- It is possible to achieve higher air exchange efficiency than in using mixing ventilation and more or less same as using displacement ventilation.

-It offers possibility of jet entrainment as in mixing ventilation.

-Air heated before entering into the room, in contrast to displacement ventilation. For that reason, this type of system has potential applications for heating and cooling rooms.

-Number of particles in the air and allergic substances in the air are less than in traditional supply systems.

Therefore, more efficient ventilation systems in the occupied zone is achieved compared to a displacement ventilation system, Awbi [2003]. However, the draught sensation taken into account when designing such systems, since the high velocity might occur in the occupied zone. Therefore, the flow behavior of IJV system investigated carefully to enable proper design to achieve better thermal comfort environment. Compared with the widely used displacement ventilation (DV) system, which known for its high ventilation efficiency benefiting from the stratification principle, Yuan, et.al. [1998], IJV retains the strength of DV while overcoming the drawback of its low momentum supply. Thus, a better ventilation of the occupied zones achieved by IJV than DV, since air supplied by IJV has sufficient momentum to overcome the buoyancy force generated from heat sources and hence reach further regions of the room. However, adopting such systems, i.e., IJV and DV, requires cooled and fresh air directly supplied to the occupied zone, which could raise the potential risks of local thermal discomfort, i.e., draught due to cold air movement close to the floor, as well as excessive temperature stratification in occupied space, Melikov, et.al. [1990].

Traditional mixing ventilation (MV) systems, which driven by high jet momentum force, still occupy a large portion of the market although in many cases has poor ventilation efficiency and is less energy efficient. In displacement ventilation, (DV) fresh air usually supplied at floor level with an inlet velocity $<0.5 \mathrm{~m} / \mathrm{s}$ and temperature $\geq 18^{\circ} \mathrm{C}$ and the cool air rises as it encounters heat sources in the room thus creating a temperature stratification. However, DV alone only used for cooling. Recently, a new method of air distribution developed by Air Innovation in Sweden that based on the impinging jet principle, Cho1, et.al. [2002]. As a medium momentum supply device (DV < IJV momentum < MV). Impinging Jet Ventilation (IJV) can combine the positive 
effects of both mixing and displacement system. It produces higher momentum than displacement ventilation and can result in the jet spreading evenly over the floor, Chen, et.al. [2013].

The objectives of the work is to conducted (CFD) study to obtain the airflow and temperature distribution for each of the three ventilation systems to estimate the actually magnitude of the inlet air flow rate and temperature needed for best ventilation, and notes the influence on air flow pattern and temperature distribution around occupants due to multiple heat sources. In addition, present study obtained the comparison between Impinging Jet Ventilation (IJV), displacement and mixing ventilation to investigate the indoor air quality and human thermal comfort under Iraqi climate.

\section{CFD SIMULATIONS}

ANSYS FLUENT 15 code software was used to simulate the present case as explained in the following section:

\section{Numerical Details}

The dimensions of Isothermal tested room are $(3 * 1.75 * 3) \mathrm{m}$ as shown in Fig. (1-a) for impinging jet ventilation under the same conditions. The supply air outlet for IJV (type-I) was located at the north wall and the exhaust grille located below the ceiling on the north sidewall, with the airflow rate equal $20.15 \mathrm{l} / \mathrm{s}$, and supply temperature $18^{\circ} \mathrm{C}$. The schematic diagram of the modeled room shown in Figs. (2-a \& 3-a) for displacement and mixing ventilation systems respectively. The supply air outlet for DV (type - II) was located at the corner between north and east wall and the exhaust grille located below the ceiling on the south sidewall. In addition, the supply air outlet for MV (type-III) was located at the corner between north and east wall and the exhaust grille located below the ceiling on the south sidewall. Which furnished for one person's simulator (shape of human body properties represented by using manikin). The elevation of human manikin is $1.1 \mathrm{~m}$ (breathing zone) for a person at sitting situation, with heat source of $75 \mathrm{~W}$, having the same surface area and releasing heat similar to a human, one PC-simulator $(45 \mathrm{~W})$, one tables, one lamp $(100 \mathrm{~W})$ were placed as a heat source, one door located at west side. In addition, the impinging, mixing and displacement ventilation under the same condition.

The dimension of the tested room for non-isothermal study are $(4 * 3.5 * 3.75) \mathrm{m}$ as shown in Fig (1-b). The supply air outlet for IJV was located at the south wall and the exhaust grille located below the ceiling on the south sidewall. The walls for tested room are partitions among rooms with the airflow rate is $50.48 \mathrm{l} / \mathrm{s}$, supply temperature $20^{\circ} \mathrm{C}$. The supply air diffuser was located at the south wall and the outlet grill placed in the center of the window at the north wall. The schematic diagram of the modeled room shown in Figs. (2-b\& 3-b) for displacement and mixing ventilation systems respectively. The supply air diffuser for DV was located at the south wall and the exhaust grille located below the ceiling on the north sidewall. In addition, the supply air diffuser for MV was located at the south wall and the exhaust grille located below the ceiling on the north sidewall. Two occupant (150W), two computer (90W) and two florescent lights $(280 \mathrm{~W})$ placed as heat sources.

The air diffusion (distribution) performance index (ADPI) is a percentage of the number of points measured in an occupied zone where EDT is within the set limit $\left(>-1.7^{\circ} \mathrm{C}\right.$ and $\left.<1.1^{\circ} \mathrm{C}\right)$ over the total number of points measured in it Chen \& Glicksman , [2003]. ADPI of 60 to 69 considered as unsatisfactory, 70 to 79 as satisfactory and 80 and above as good air distribution.

The boundary conditions specified as follows: The working fluid used is air and the flow assumed to be steady, three-dimensional, incompressible fluid, Newtonian and turbulent flow. The ANSYS FLUENT15 code software was used to generate the model and meshed case study depending on many testing meshes then analyses by using ANSYS FLUENT15 code software 
until the residual error for solved equations arrived to $\left(10^{-3}\right)$ and $\left(10^{-6}\right)$ for energy equation. Second-order upwind scheme using for the convection terms. PRESTO (Pressure Staggering Option) scheme used for the pressure. For the pressure-velocity, coupling the SIMPLEC scheme used. When working with unstructured meshes, a high-order scheme is preferred for the discretization of convection terms to minimize the discretization errors. The boundary conditions and assumptions obtained are shown in tables $1 \& 2$.

\section{Dimensions of Supply Air Outlets}

In impinging (type-I), displacement (type-II), and mixing (type-III) ventilation systems there are some goals should be investigated for the airflow and temperature fields, thermal comfort as well as ventilation effectiveness with respect to heat removal effectiveness and air exchange efficiency for each of the iso-thermal and non iso-thermal room.

In present work, the IJV system used a square cross sectional area of supply air duct at outlet height equal $0.1 \mathrm{~h}$ from the room foot level. The supply air velocity selected equal $2.5 \mathrm{~m} / \mathrm{s}$. Then dimensions of outlet across sectional area can obtained, Qasim, et.al. [2014]:

$$
\mathrm{Q}_{\mathrm{s}}=\mathrm{u}_{\mathrm{x}} * \mathrm{~A}_{\mathrm{s}}
$$

The dimensions of supply air outlets for each type of ventilation systems are listed in tables $3 \& 4$.

\section{The Mathematical Model}

The working fluid used is air and the flow assumed to be steady, three-dimensional, incompressible, Newtonian and turbulent.

The governing equations of motion based on Navier-Stockes conservation equations form for continuity, momentum and energy equations as follows, Ren \& Zhang, [2007] .

$$
\frac{\partial}{\partial x}(\rho U)+\frac{\partial}{\partial y}(\rho V)+\frac{\partial}{\partial z}(\rho W)=0
$$

$\frac{\partial}{\partial x}(\rho U U)+\frac{\partial}{\partial y}(\rho U V)+\frac{\partial}{\partial z}(\rho U W)=-\frac{\partial p}{\partial x}+\frac{\partial}{\partial x}\left(\mu \frac{\partial U}{\partial x}\right)+\frac{\partial}{\partial y}\left(\mu \frac{\partial U}{\partial y}\right)+\frac{\partial}{\partial z}\left(\mu \frac{\partial U}{\partial z}\right)$

$+\frac{1}{3} \frac{\partial}{\partial x}\left[\mu\left(\frac{\partial U}{\partial x}+\frac{\partial V}{\partial y}+\frac{\partial W}{\partial z}\right]+\rho g_{x}\right.$

$\frac{\partial}{\partial x}(\rho U V)+\frac{\partial}{\partial y}(\rho V V)+\frac{\partial}{\partial z}(\rho V W)=-\frac{\partial p}{\partial y}+\frac{\partial}{\partial x}\left(\mu \frac{\partial V}{\partial x}\right)+\frac{\partial}{\partial y}\left(\mu \frac{\partial V}{\partial y}\right)+\frac{\partial}{\partial z}\left(\mu \frac{\partial V}{\partial z}\right)$

$+\frac{1}{3} \frac{\partial}{\partial y}\left[\mu\left(\frac{\partial U}{\partial x}+\frac{\partial V}{\partial y}+\frac{\partial W}{\partial z}\right]+\rho g_{y}\right.$

$\frac{\partial}{\partial x}(\rho U W)+\frac{\partial}{\partial y}(\rho V W)+\frac{\partial}{\partial z}(\rho W W)=-\frac{\partial p}{\partial z}+\frac{\partial}{\partial x}\left(\mu \frac{\partial W}{\partial x}\right)+\frac{\partial}{\partial y}\left(\mu \frac{\partial W}{\partial y}\right)+\frac{\partial}{\partial z}\left(\mu \frac{\partial W}{\partial z}\right)+$

$\frac{1}{3} \frac{\partial}{\partial z}\left[\mu\left(\frac{\partial U}{\partial x}+\frac{\partial V}{\partial y}+\frac{\partial W}{\partial z}\right]+\rho g_{z}\right.$

$\frac{\partial}{\partial x}(\rho U T)+\frac{\partial}{\partial y}(\rho V T)+\frac{\partial}{\partial z}(\rho W T)=\frac{\partial}{\partial x}\left(\Gamma \frac{\partial T}{\partial x}\right)+\frac{\partial}{\partial y}\left(\Gamma \frac{\partial T}{\partial y}\right)+\frac{\partial}{\partial z}\left(\Gamma \frac{\partial T}{\partial z}\right)$

Where:

(Г) Is the diffusion coefficient (diffusivity), which is given by:

$\Gamma=\frac{\mu}{\sigma}$ 


\section{Turbulence Model}

RNG K-E turbulence model used with the equations is, Ren \& Zhang [2007]:

$$
\begin{aligned}
& \rho U_{i} \frac{\partial k}{\partial x_{i}}=\mu_{t} S^{2}+\frac{\partial}{\partial x_{i}}\left[\alpha_{k} \mu_{e f f} \frac{\partial k}{\partial x_{i}}\right]-\rho \varepsilon \\
& \rho U_{i} \frac{\partial \varepsilon}{\partial x_{i}}=C_{1 \varepsilon}\left(\frac{\varepsilon}{k}\right) \mu_{t} S^{2}+\frac{\partial}{\partial x_{i}}\left[\alpha_{k} \mu_{e f f} \frac{\partial k}{\partial x_{i}}\right]-C_{2 \varepsilon} \rho\left(\frac{\varepsilon^{2}}{k}\right)-R
\end{aligned}
$$

The value of model constants are: $C_{1 \varepsilon}=1.42$ and $C_{2 \varepsilon}=1.68$

Air speed is used to determine the effective draft temperature, from which the air diffusion (distribution) performance (ADPI) can be calculated. This parameter is useful in describing the diffusion performance of air for a diffuser in a ventilated space, Iraqi Cooling Code,[2012].

$\mathrm{ADPI}=(\mathrm{N} \theta / \mathrm{N}) * 100$

Ventilation effectiveness, another parameter is used to confirm the results that obtained from (ADPI), and can be calculated by using the following equation:

$$
\varepsilon_{t}=\frac{T_{0}-T_{i}}{T_{m}-T_{i}}
$$

\section{RESULTS AND DISCUSSION}

Figs. $4 \& 5$ show a comparison results between the three ventilation types that investigated the contours of air temperature distribution in the isothermal room at a plane location $(\mathrm{z}=0.875 \mathrm{~m}$, $\mathrm{y}=0.1 \mathrm{~m})$, and non-isothermal tested room at a plane location $(\mathrm{z}=1.75 \mathrm{~m}, \mathrm{y}=0.1 \mathrm{~m})$. The temperature increases from $18{ }^{\circ} \mathrm{C}$ closely at the supply air terminal and reach about $30^{\circ} \mathrm{C}$ near the human body and (PC) simulater. The cold air expands through the floor of the room and then passes vertically since a hot air due to heat exchange with heat sources in the room (occupants \& appliances). Thermal plumes generated by convection due to the differences in temperature between the heat sources and the surrounding air.

It found that the floor region near the supply diffuser zone would show the lowest temperature values, due to the cooling effect of the supply entering air. In addition, a gradual increase in temperature obtained as elevation increase inside the room. Also, an increase in indoor temperature can be noted near the person, PC-simulator and lighting.

Figs. $6 \& 7$ show a comparison results between the three ventilation types by obtaining the flow field patterns as air velocity distribution for each of isothermal and non-isothermal tested rooms. A buoyancy-driven thermal plume develops near the body due to the temperature gradient between the body surface and ambient air. The air moves horizontally over the floor due to momentum from the supply outlet air and suction from thermal plumes. It then passes vertically to a high level in the room where it is exhausted from the exhaust grills. Vertical air movement between layers caused by strong convection forces associated with heat sources (occupant \& computer).

Acceptable values of Air Distribution Performance Index (ADPI), effective temperature and ventilation efficiency is determined. Impinging Jet Ventilation (IJV) system gives efficient results better than Mixing Ventilation (MV) and Displacement Ventilation (DV) systems for isothermal and non-isothermal tested rooms as listed in tables $5 \& 6$, Also good air distribution system not only promotes a comfortable and healthy environment for occupants, but also contributes to energy conservation. 


\section{CONCLUSIONS}

The present study focuses on a comparison between three types of ventilation systems to predict airflow field and temperature distribution under Iraqi climate. Impinging Jet Ventilation system with square cross sectional area supply duct gives good results for indoor air quality and thermal human comfort when compared with other two ventilation types (mixing and displacement ventilation systems) for both case studies of tested rooms (isothermal and nonisothermal rooms)..

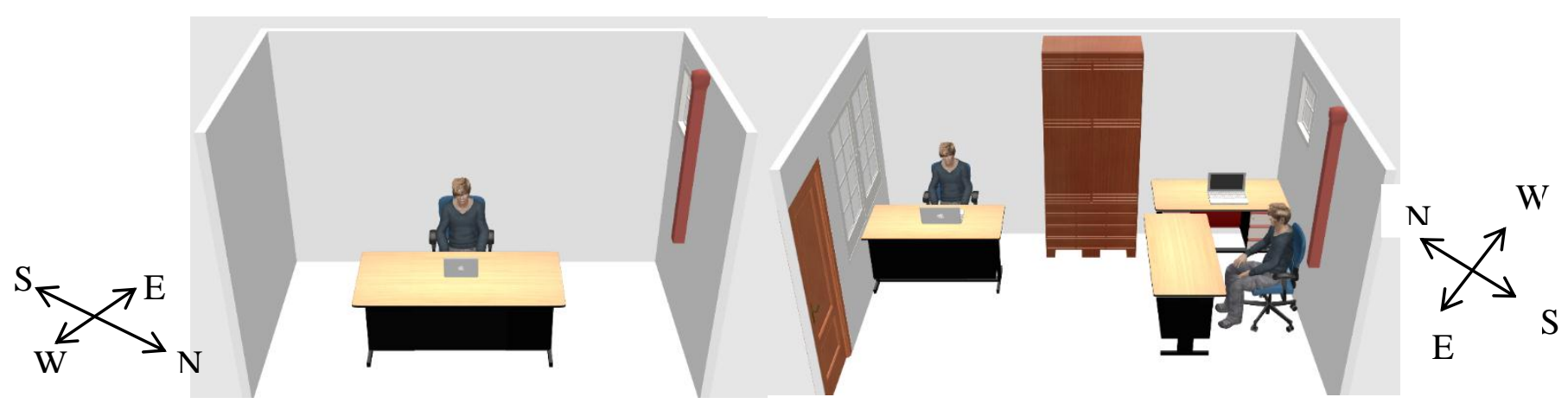

a- iso-thermal tested room b- non-isothermal tested room

Fig. 1 : Schematic diagram of tested room adopting IJV System

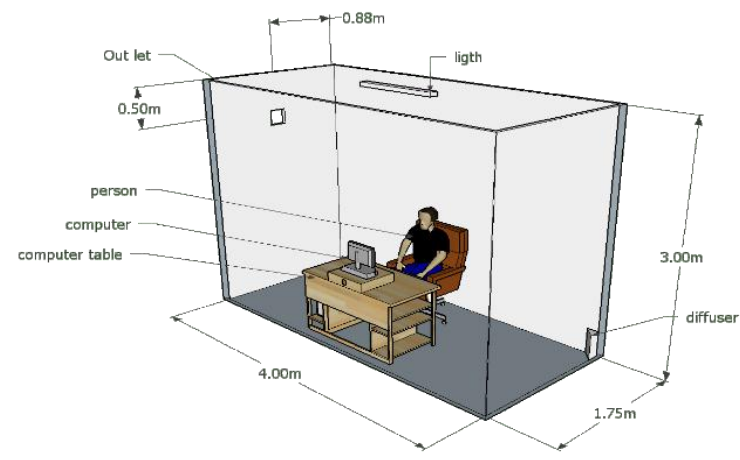

a- iso-thermal tested room

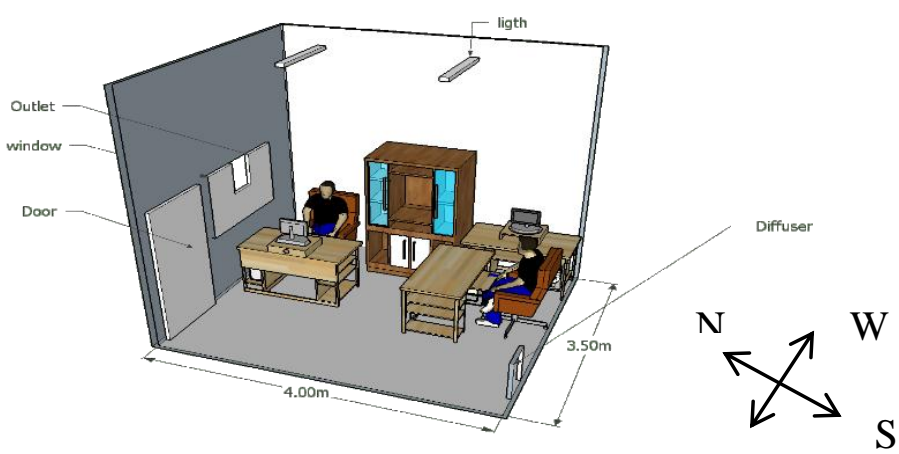

$\mathrm{E}$

b- non-isothermal tested room

Fig. 2 : Schematic diagram of tested room adopting DV system 


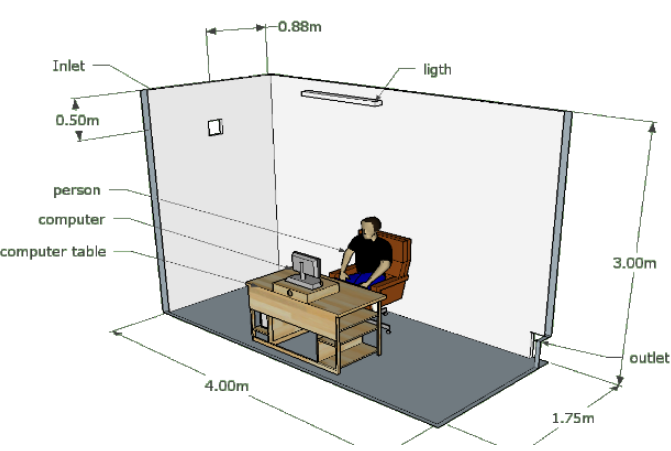

a- iso-thermal tested room

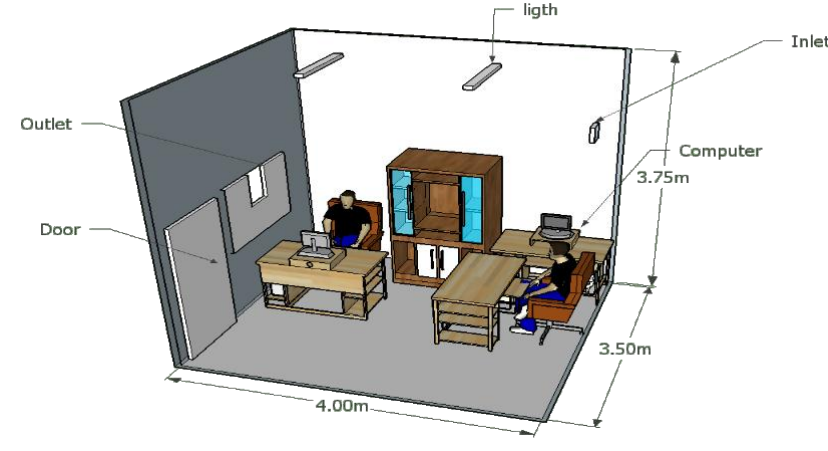

b- non-isothermal tested room

Fig. 3: Schematic diagram of tested room adopting MV system

Table 1: Boundary Conditions

\begin{tabular}{|c|c|c|c|}
\hline \multirow{2}{*}{ Item } & \multirow{2}{*}{ Consideration } & \multicolumn{2}{|c|}{ Momentum conditions } \\
\cline { 3 - 4 } & & Wall motion & Shear condition \\
\hline Person & Wall & Stationary & No Slipping \\
\hline Computer & Wall & Stationary & No Slipping \\
\hline Side walls, floor, ceil, & Wall & Stationary & No Slipping \\
\hline Tables and lights & Wall & Stationary & No Slipping \\
\hline Supply air duct & velocity inlet & \multicolumn{2}{|c|}{ magnitude, normal to boundary } \\
\hline & & -Gauge Pressure $=$ (0 Pascal), [constant]. \\
& & \multicolumn{2}{|c|}{ Backflow direction specification } \\
Extract air grill & Pressure outlet & \multicolumn{2}{|c|}{ method: (normal to boundary). } \\
& & Tsp $=18^{\circ} \mathrm{C}$ (isothermal test room) \\
& & Tsp $=20^{\circ} \mathrm{C}$ (non-isothermal test room) \\
\hline
\end{tabular}

Table 2: Solution methods

\begin{tabular}{|c|c|}
\hline Fluid flow(fluent) & Solution methods \\
\hline Scheme & SIMPLEC \\
\hline Pressure & Standard \\
\hline Momentum & Second order \\
\hline Turbulent kinetic energy & Second order \\
\hline Turbulent dissipation rate & Second order \\
\hline
\end{tabular}

Table 3: Dimensions of supply air outlets for isothermal room

\begin{tabular}{|c|c|c|c|}
\hline Ventilation system & IJV(Type-I $)$ & $\begin{array}{c}\text { DV(Type-II), Zahraa } \\
\text { \&. Ala'a , [2016] }\end{array}$ & $\begin{array}{c}\text { MV(Type-III), } \\
\text { Zahraa \& Ala'a, } \\
{[2016]}\end{array}$ \\
\hline Outlet area $\left(\mathrm{m}^{2}\right)$ & 0.0144 & 0.736 & 0.084 \\
\hline Exhaust grille area $\left(\mathrm{m}^{2}\right)$ & 0.011144 & 0.04 & 0.04 \\
\hline
\end{tabular}


Table 4: Dimensions of supply air outlets for non-isothermal room

\begin{tabular}{|c|c|c|c|}
\hline Ventilation system & IJV(Type-I) & $\begin{array}{c}\text { DV(Type-II), Zahraa } \\
\text { \& Ala'a , [2016] }\end{array}$ & $\begin{array}{c}\text { MV(Type-III ), } \\
\text { Zahraa \& Ala'a, } \\
{[2016]}\end{array}$ \\
\hline Outlet area $\left(\mathrm{m}^{2}\right)$ & 0.0144 & 0.5 & 0.12 \\
\hline Exhaust grille area $\left(\mathrm{m}^{2}\right)$ & 0.175 & 0.16 & 0.16 \\
\hline
\end{tabular}

Table 5: A comparison results of ADPI \& ventilation effectiveness for isothermal test room

\begin{tabular}{|c|c|c|c|}
\hline $\begin{array}{c}\text { Type of } \\
\text { ventilatio } \\
\text { n system }\end{array}$ & IJV & DV & MV \\
\hline ADPI \% & 0.80 & 70.9 & 79.8 \\
\hline $\boldsymbol{\varepsilon}_{\mathrm{t}}$ & 1.09 & 1.06 & 0.42 \\
\hline
\end{tabular}

Table 6: A comparison results of ADPI \& ventilation effectiveness for non-isothermal test room

\begin{tabular}{|c|c|c|c|}
\hline $\begin{array}{c}\text { Type of } \\
\text { ventilatio } \\
\text { n system }\end{array}$ & IJV & DV & MV \\
\hline ADPI \% & 0.83 & 75.6 & 68.1 \\
\hline $\boldsymbol{\varepsilon}_{\mathbf{t}}$ & 1.034 & 1.086 & 0.25 \\
\hline
\end{tabular}




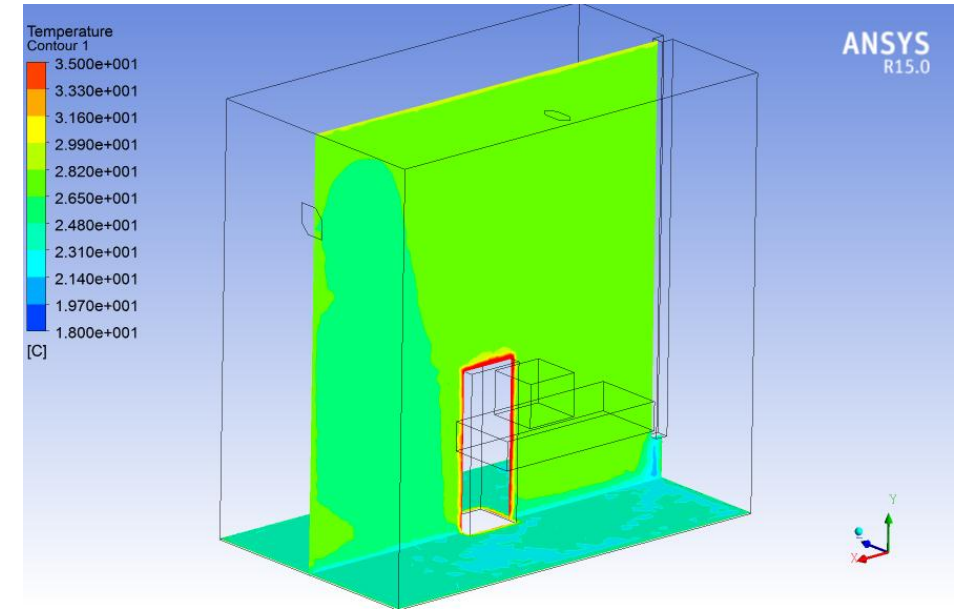

a. Adopting IJV system

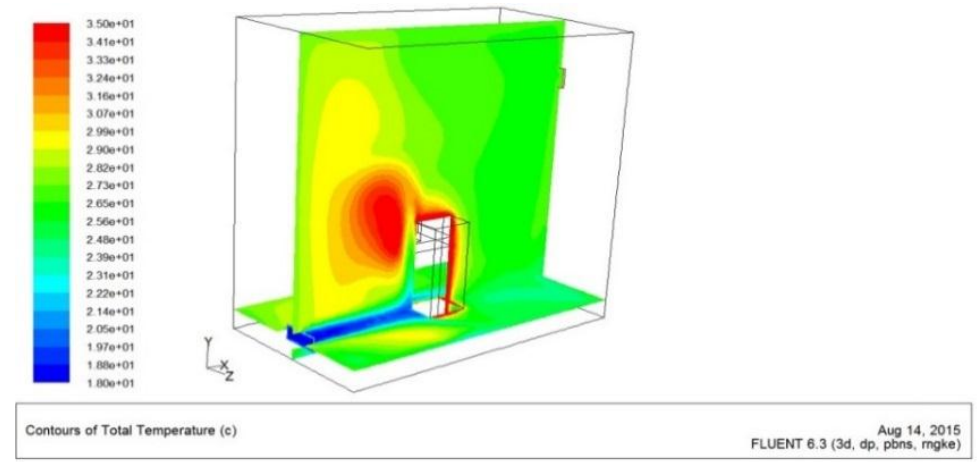

b. Adopting DV system, Ali \& Ala'a, [2016]

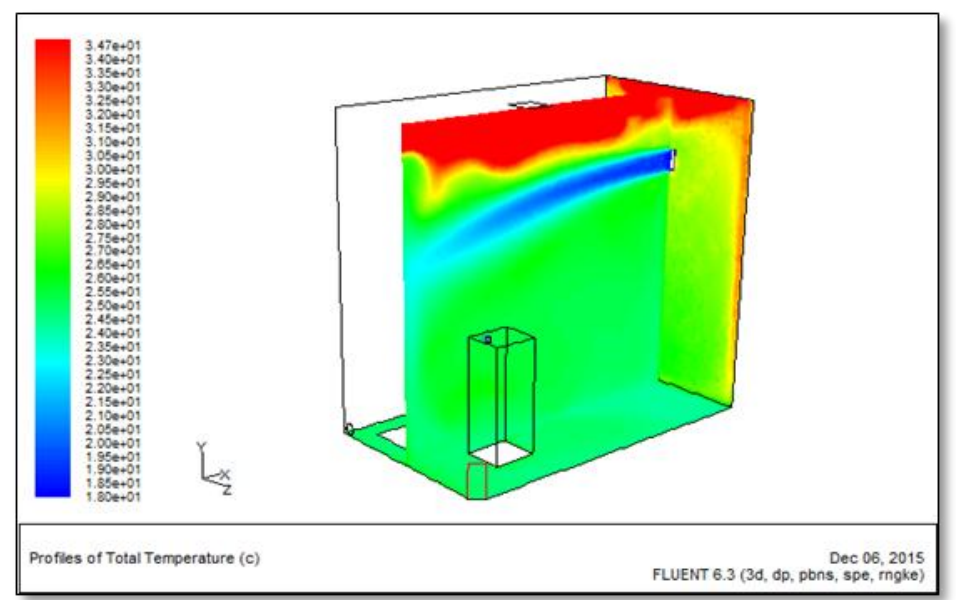

c. Adopting MV system, Ali \& Ala'a , [2016]

Fig. 4: Temperature distribution contours for isothermal test room at $\mathrm{z}=0.875 \mathrm{~m}, \mathrm{y}=0.1 \mathrm{~m}$ 


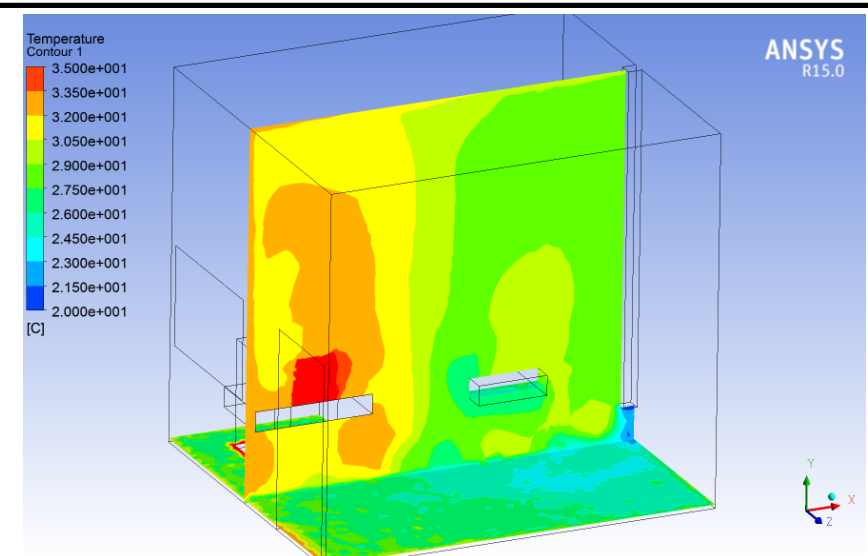

a. Adopting IJV system

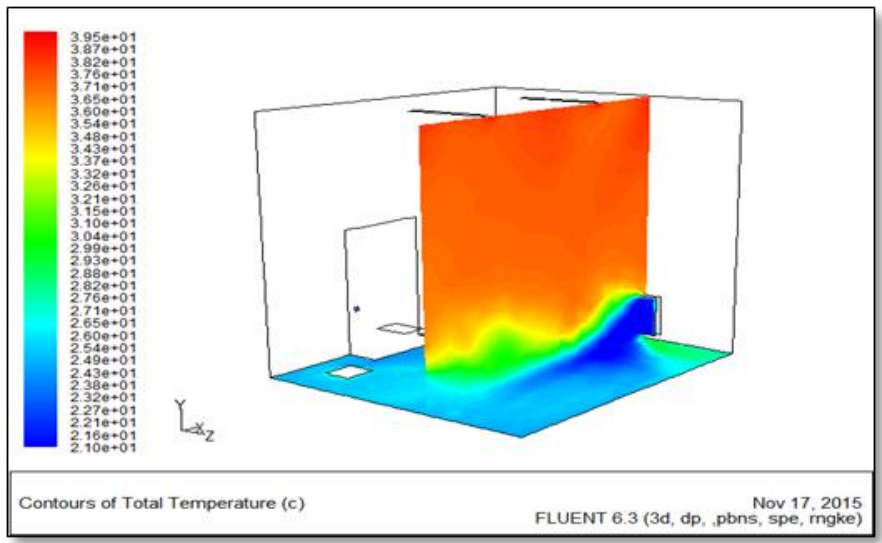

b. Adopting DV system, Zahraa \& Ala'a, [2016]

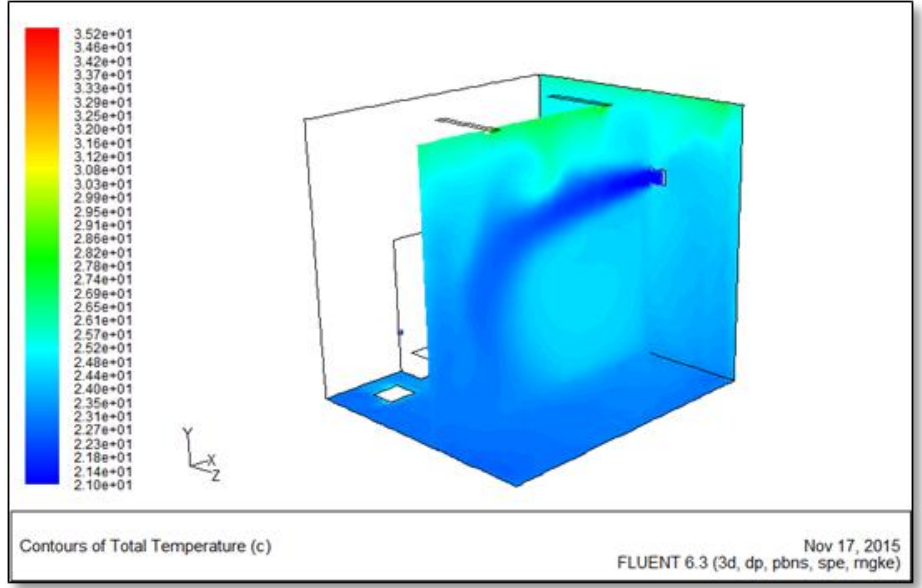

c. Adopting MV system, Zahraa \& Ala'a ,[2016]

Fig. 5 Temperature distribution contours for non-isothermal test room at $\mathrm{z}=1.75 \mathrm{~m}, \mathrm{y}=0.1 \mathrm{~m}$ 


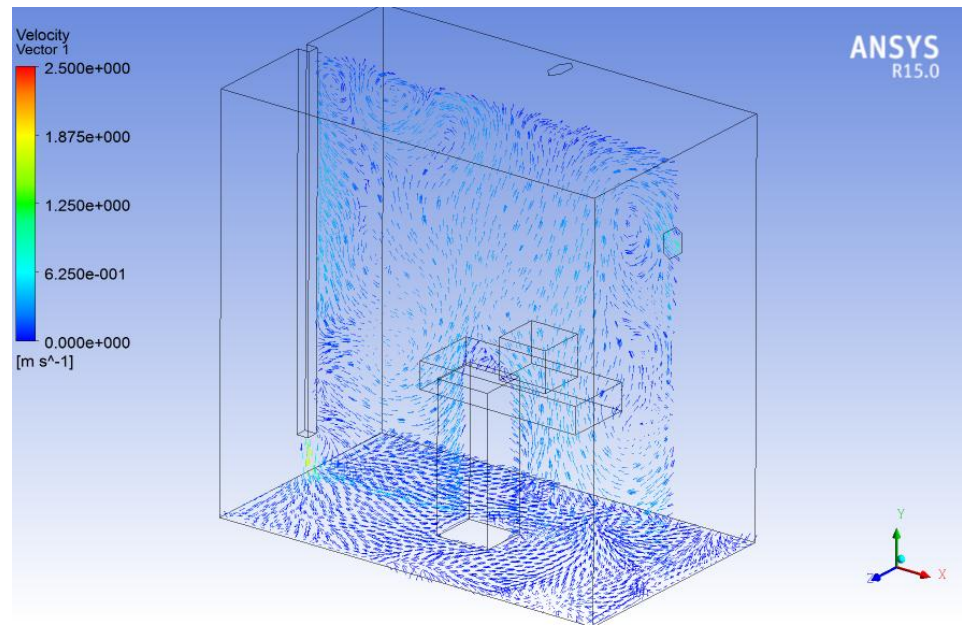

a. Adopting IJV system

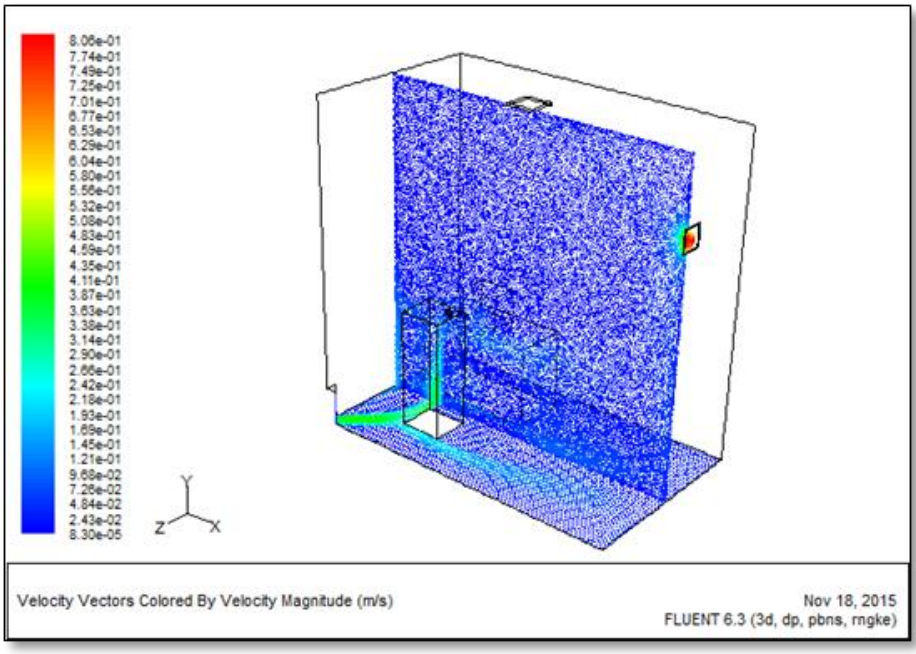

b. Adopting DV system, Zahraa \& Ala'a, [2016]

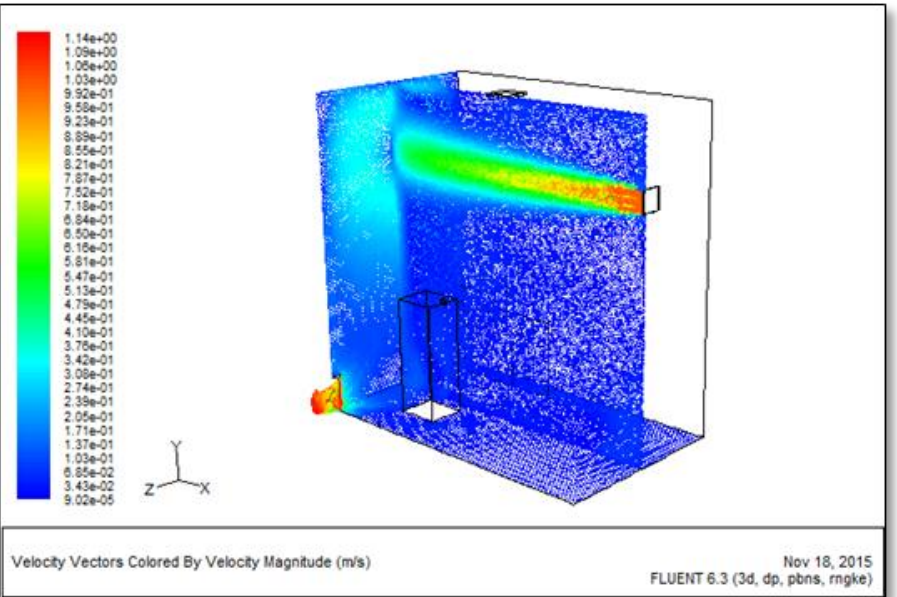

c. Adopting MV system, Zahraa \& Ala'a , [2016]

Fig. 6 Velocity vectors distribution for isothermal test room at $\mathrm{z}=0.875 \mathrm{~m}, \mathrm{y}=0.1 \mathrm{~m}$ 


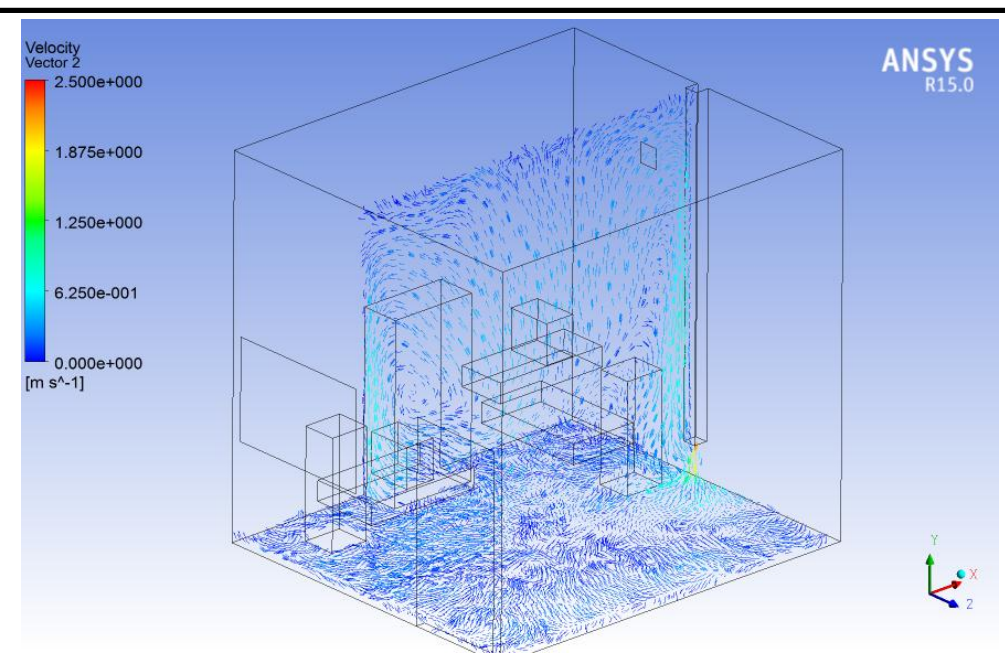

a. Adopting IJV system

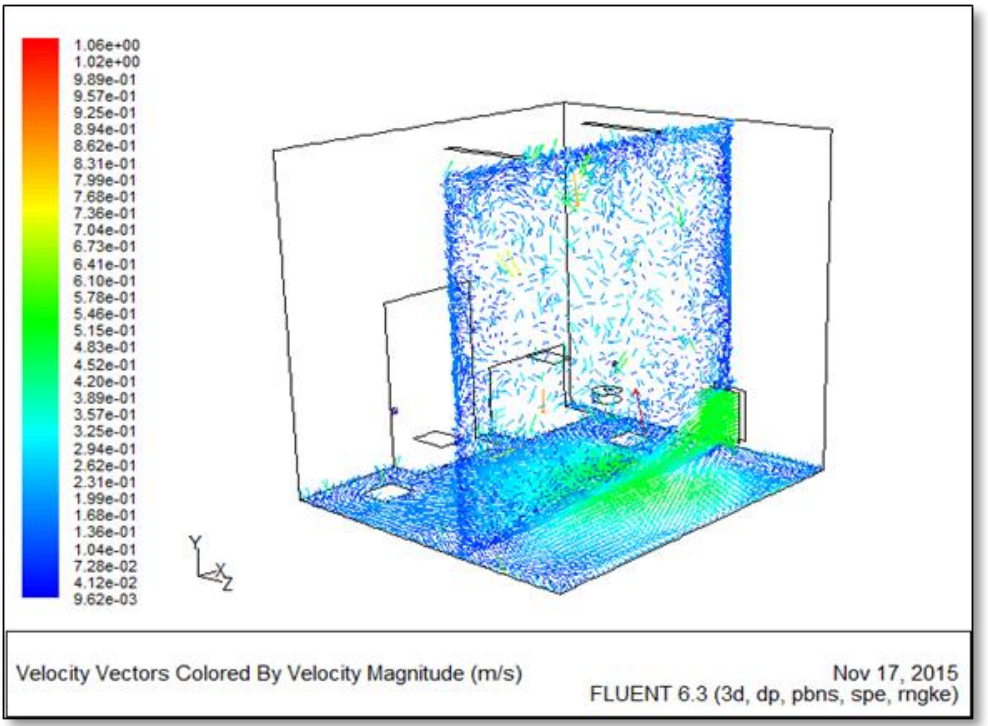

b. Adopting DV system, Zahraa \&Ala'a , [2016]

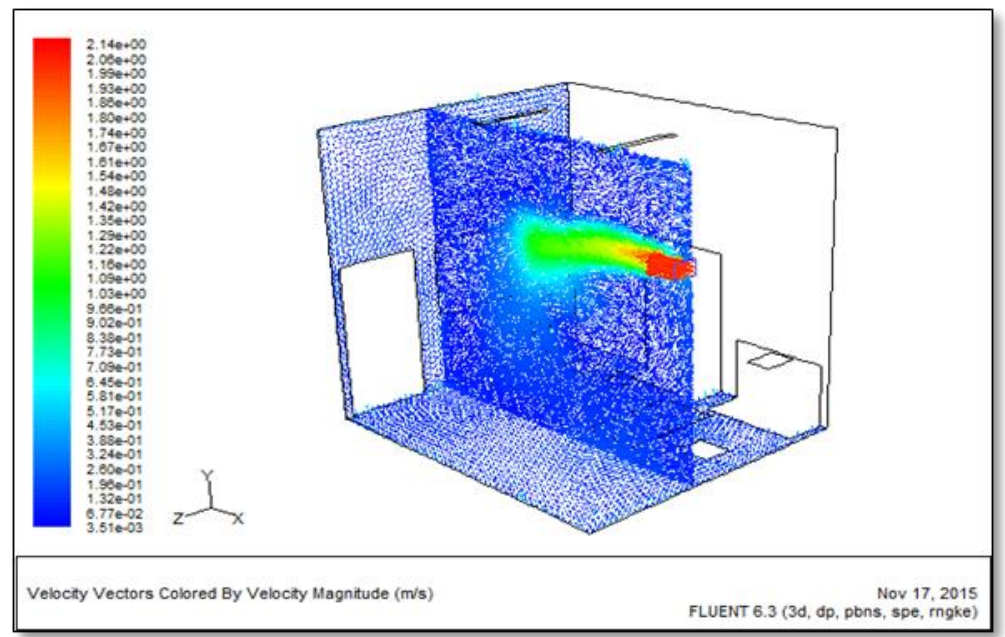

c. Adopting MV system. Zahraa \& Ala'a , [2016]

Fig. 7 Velocity vectors distribution for non-isothermal test room at $z=1.75 \mathrm{~m}, y=0.1 \mathrm{~m}$ 


\section{REFERENCES:}

Awbi HB, "Ventilation of buildings", Second Ed. London: Spon Press; 2003.

Ali Aedan \& Dr. Ala'a Abbas Mahdi, "Experimental and numerical investigation of displacement ventilation system with assessment of four turbulence models", M.Sc. thesis, University of Babylon, Iraq, 2016.

Chen, Q. \& Glicksman, L., "System performance evaluation and design guidelines for displacement ventilation", Section E G, Atlanta, GA: American Society of Heating, Refrigerating, and Air-conditioning Engineers, Inc., 2003.

Hakon Skistad, "displacement ventilation and air curtain zoning” Kolbj. Hejesvei 1D, NO 7465 Trondheim, Norway, 2010.

Huijuan Chen a,b,*, Bahram Moshfegh ${ }^{\text {a,b }}$, Mathias Cehlina, "Computational investigation on the factors influencing thermal comfort for impinging jet ventilation", University of Gavle, 80176 Gavle, Sweden, 2013.

Iraqi cooling code, 2012.

Melikov AK, Langkilde G, Derbiszewski B. Airflow characteristics in the Occupied zone of rooms with displacement ventilation. ASHRAE Transactions 1990.

Qasim H., Dr. Ala'a Abbas Mahdi, Dr. Sabah Tariq, "Numerical study of air velocity and temperature distribution by displacement ventilation", M.SC. Thesis, University of Technology, Baghdad, Iraq, (2014).

T.Karimipanah ${ }^{\mathrm{a}}$, H.B. Awbi $\mathrm{i}^{\mathrm{b}, *}$ "Theoretical and experimental investigation of impinging jet ventilation and comparison with wall displacement ventilation", The University of Reading, reading RG6 6AW, UK, 2001.

Yuan XX, Chen QY, Glicksman LR. "A critical review of displacement ventilation". ASHRAE Transactions 1998.

Y Cho1, H B Awbi1 , T Karimipanah2" a comparison between four different ventilation systems ”,the University of Reading, UK ${ }^{2}$ Air Innovation AB, Sweden, 2002.

Y. Ren, D. Li, Y. Zhang, "Numerical Simulation of Thermal Comfort Degree in Radiant Floor Cooling Room" Building Simulation,2007.

Zahraa Hassan \& Dr. Ala'a Abbas Mahdi, "Study on Air Flow Diffusion and Contaminants Circulation in Room Ventilation Relate with Iraqi Climate", M.Sc. thesis, University of Babylon, Iraq, 2016. 